\title{
Analisis Kepuasan Mahasiswa dalam Pelaksanaan Pembelajaran Online di Era Pandemi Covid-19
}

\author{
Appin Purisky Redaputri ${ }^{1]}$, Yanuar Dwi Prastyo ${ }^{2]}$, M. Yusuf S Barusman ${ }^{3]}$ \\ Universitas Bandar Lampung \\ E-mail: ${ }^{1]}$ appin@ubl.ac.id \\ ${ }^{2]}$ yanuar@ubl.ac.id \\ ${ }^{3]}$ yusuf.barusman@ubl.ac.id
}

\begin{abstract}
Abstrak
Pembelajaran secara online saat ini harus dilakukan karena adanya pandemi Covid-19 ini. Termasuk pada tingkat peguruan tinggi. Salah satu Universitas swasta di Bandar Lampung yaitu Universitas Bandar Lampung (UBL). UBL sudah lama menerapkan blended learning dengan menggunakan sistem bernama UBLApps. Namun sistem yang tersedia belum tentu bisa membuat proses belajar mengajar mencapai tujuannya. Pemahaman para mahasiswa mengenai apa yang diperlajari merupakan esensi dari kegiatan belajar mengajar. Untuk itu perlu diketahui seberapa jauh kesiapan mahasiswa untuk menggunakan sistem UBLApps dari sisi pemahaman dan infrastruktur. Penelitian ini merupakan penelitian yang menggunakan analisis deskriptif. Dengan jumlah populasi semua mahasiswa aktif Universitas Bandar Lampung yang aktif yang mengikuti pembelajaran online sebanyak 5.175 orang mahasiswa. Jumlah sampel penelitian ditetapkan sebanyak 561 orang yang dapat mewakili populasi dengan menggunakan simple random sampling. Hasil penelitian ini diketahui bahwa mahasiswa sudah siap melaksanakan program pembelajaran online dengan infrastruktur jaringan internet yang memadai. Kemudian dari sisi pembelajaran online, mahasiswa lebih memilih kuliah online dari pada offline dan model interaksi campuran antara tatap muka dan tanpa tatap muka. Mahasiswa juga sebagian besar sudah merasa paham dengan materi yang diberikan dan puas dengan pembelajaran online yang sudah dijalankan di UBL. Dalam mengahadapi era new normal, Universitas Bandar Lampung juga menerapkan flexi learning. Sebagian besar mahasiswa setuju dengan adanya penerapan flexi learning, namun jika diperbolehkan untuk memilih lebih banyak mahasiswa yang menginginkan untuk kuliah secara offline jika kondisi memungkinkan.
\end{abstract}

Kata Kunci: Kepuasan,Pembelajaran Online, Covid-19

\section{Analysis of Student Satisfaction in Online Learning Implementation in the Covid-19 Pandemic Era}

Online learning must now be done because of the Covid-19 pandemic. One of the private universities in Bandar Lampung is Bandar Lampung University (UBL). UBL has long been implementing blended learning by using a system called UBLApps. Students' understanding of what is learned is the essence of teaching and learning activities. For that, it is necessary to know how far the readiness of students to use the UBLApps system in terms of understanding and infrastructure. The research design used is descriptive analysis. The population in this 
study were all active Bandar Lampung University students who took part in online learning. The results of this study note that students are ready to carry out online learning programs with adequate internet network infrastructure. Then in terms of online learning, students prefer online lectures rather than offline and mixed interaction models face to face and without face to face. Most students also already understand the material provided and are satisfied with online learning that has been carried out at UBL. In facing the new normal era, Bandar Lampung University also applies flexi learning. Most students agree with the application of flexi learning. But if you are allowed to choose more students who want to study offline if conditions allow.

Keywords: Satisfaction, Online Learning, Covid-19.

\section{PENDAHULUAN}

Pandemi COVID-19 merupakan sebuah peristiwa menyebarnya virus yang bernama corona, yang dimulai dari Wuhan, Cina pada tahun 2019. Banyak hal terdampak pandemi COVID-19. Dari mulai bidang perekonomian, sosial dan juga dunia pendidikan. Bidang perekonomian misalnya, banyak sekali para pekerja yang dirumahkan sementara atau bahkan diputuskan hubungan kerjanya dengan Perusahaan akibat adanya Pandemi Covid-19. Selain memang diwajibkan pembatasan sosial, perusahaan juga banyak yang mengalami ketidakstabilan perekonomian usahanya, sehingga perusahaan tidak memiliki pilihan selain merumahkan sementara maupun memberhentikan pekerjanya. Selain dari sisi perekonomian, di bidang pendidikan, menurut UNESCO, pada bulan April 2020, 1,6 miliar pelajar diliburkan dari sekolah dan universitas, hal ini sebagai langkah pihak penyelenggara pendidikan untuk menekan penyebaran Covid-19 (bbc, 2020). Angka tersebut kurang lebih 90\% dari seluruh populasi siswa di dunia. Upaya meliburkan para siswa dan mahasiswa ini, bukan hanya benarbenar meliburkan mereka, tapi merubah sistem pembelajarannya, dari yang biasanya bertemu langsung menjadi online.
Adanya berbagai kondisi baru di dalam sistem belajar dan mengajar, membuat para pelaku di dunia pendidikan dan para siswa dan mahasiswa belum siap untuk menyesuaikan diri. Terdapat dampak yang dirasakan oleh semua pihak terkait pendidikan, baik dari sisi siswa dan mahasiswa serta dari sisi pengajar. Dampak yang dirasakan oleh banyak keluarga di Indonesia yaitu bahwa banyak keluarga yang belum terbiasa melakukan kegiatan belajar dan mengajar dari rumah. Selain keluarga, para tenaga pengajar juga belum terbiasa dengan sistem pembelajaran online. Siswa dan mahasiswa yang terbiasa belajar bertatap muka langsung dengan pengajar mereka, hanya bisa melakukan pertemuan secara virtual. Namun mau tidak mau pembelajaran secara online tetap harus dilakukan karena belum ada kepastian mengenai penyelesaian pandemi Covid-19 ini.

Termasuk pada tingkat peguruan tinggi, mahasiswa dan para dosen yang tidak pernah melakukan proses belajar mengajar menggunakan aplikasi sistem dan pengajaran virtual dengan aplikasi online, juga harus belajar untuk bisa cepat menyesuaikan. Salah satu Universitas swasta di Bandar Lampung yaitu Universitas Bandar Lampung (UBL) sebenarnya sudah lama menerapkan blended learning dengan menggunakan sistem bernama 
UBLApps. Namun penggunaannya hanya sebatas untuk absensi dan upload materi. Sudah ada interaksi seperti pengerjaan tugas, UTS dan UAS dengan aplikasi ini, namun belum semua dosen dan mahasiswa menggunakan. Hal ini menunjukkan bahwa paling tidak UBL sudah satu langkah lebih depan dari sisi sistem yang tersedia. Tinggal penyesuaian sistem sesuai dengan penggunaan yang dibutuhkan dalam proses belajar mengajar di era pandemic COVID-19 seperti saat ini.

Sistem yang tersedia belum tentu bisa membuat proses belajar mengajar mencapai tujuannya. Pemahaman para mahasiswa mengenai apa yang diperlajari merupakan esensi dari kegiatan belajar mengajar. Untuk itu perlu diketahui seberapa jauh kesiapan mahasiswa untuk menggunakan sistem UBLApps dari sisi pemahaman dan infrastruktur, kemudian setelah berjalan selama 3 bulan untuk pembelajaran online menggunaka UBLApps bagaimana dengan kepuasan dari Mahasiswa tentang sistem pembelajaran online yang ada di UBL.

Pembelajaran online merupakan sistem pembelajaran terbuka yang menjadikan berbagai media seperti internet, teknologi berbasis jaringan sebagai alat bantu dalam memfasilitasi terlaksananya proses belajar mengajar dan tersampaikannya ilmu pengetahuan melalui kegiatan dan interaksi (Dabbagh dan Ritland, dalam Khairuddin, 2019). Sedangkan menurut Moore, DicksonDeane, \& Galyen (2011) pembelajaran online merupakan pembelajaran untuk memunculkan berbagai jenis interaksi pembelajaran dengan menggunakan jaringan internet dengan aksesibilitas, konektivitas, dan fleksibilitas.

Menurut Dhull, I et all (2017), terdapat dua jenis pembelajaran online.
Yang pertama adalah wrap around model. Model ini bergantung pada bahan pembelajaran. Model ini mewakili pendekatan pembelajaran berbasis sumber daya, karena berusaha menggunakan materi yang ada yang relatif tidak berubah dan sudah tersedia secara online atau offline. Yang kedua adalah The Integrated Model, model ini paling dekat dengan kursus pembelajaran online lengkap. Model ini ditawarkan melalui sistem manajemen pembelajaran yang komprehensif. Materi pembelajaran untuk model ini kebanyakan dalam format elektronik seperti peluangkonferensi komputer, aktivitas pembelajaran online kolaboratif berbasis kelompok kecil dan penilaian hasil belajar online. Untuk saat ini, beberapa konten pokok bahasan mungkin paling baik dinilai secara offline di sudah diterbitkan buku teks dan sumber lainnya. Pembelajaran dan pengajaran dalam model ini membutuhkan waktu tempatkan di konferensi komputer, di mana bacaan yang ditentukan dan ditugaskan tugas dibahas. Banyak dari kegiatan belajarmengajar ini cukup lancar dan dinamis karena sangat ditentukan oleh aktivitas individu dan kelompok di dalam.

Terdapat 9 keunggulan pembelajaran online menurut Dhull, I et al ( 2017), yang pertama, pembelajaran online menyediakan aksesibilitas sehingga mahasiswa dapat belajar dari mana saja di dunia. Ini merupakan pertimbangan yang sangat penting bagi mahasiswa yang ingin belajar di negara lain.

Yang kedua, pembelajaran yang dipersonalisasi, sistem pembelajaran online memungkinkan mahasiswa untuk menentukan dan memproses gaya belajar, isi, tujuan, pengetahuan terkini dan keterampilan individu. E-Learning memungkinkan individu untuk merencanakan dan mengarahkan 
pembelajarannya sendiri. Hal ini berpotensi untuk memotivasi, mengembangkan kepercayaan diri dan harga diri bagi mahasiswa.

$$
\text { Yang ketiga adalah }
$$

mengembangkan kemampuan kognitif. Dalam sebuah penelitian, ditemukan bahwa E-Learning mungkin efektif dalam mengembangkan kognitif kemampuan murid guru (Singh \& Mishra, 2009). Ditemukan bahwa mahasiswa program elearning memiliki tingkat pencapaian yang lebih tinggi daripada rekan mereka. Seorang mahasiswa dapat menemukan informasi tanpa batas yang dapat dia akses hanya dengan mengklik sebuah tombol. Banyak program Online ditawarkan oleh beberapa universitas paling bergengsi dari seluruh dunia. Hal ini dapat bermanfaat untuk pengembangan kemampuan kognitifnya.

Yang keempat adalah efektivitas biaya. Pembelajaran Online lebih hemat biaya karena lebih sedikit uang yang dihabiskan untuk bepergian dan masuk membeli buku atau menghabiskan uang dalam konteks perguruan tinggi. Karena bisa dilakukan di lokasi geografis mana pun dan tidak ada biaya perjalanan, jenis pembelajaran ini lebih murah daripada belajar di lembaga tradisional.

$$
\text { Yang kelima adalah }
$$

mempromosikan penelitian. Mahasiswa sangat bersemangat untuk mempublikasikan hasil karyanya saat mereka menghasilkan sesuatu kualitas yang sangat tinggi.

$\begin{array}{rrr}\text { Yang } & \text { kelima } & \text { adalah } \\ \text { komputer } & \text { dasar. }\end{array}$ Mahasiswa di dalam dan di luar kampus yang memilih untuk belajar online memiliki kesempatan untuk mendapatkan keterampilan teknis dalam menggunakan Teknologi Komunikasi Informasi (TIK).Keterampilan ini kemungkinan besar akan berguna bagi mereka dalam kehidupan profesional dan masa depan mereka

Yang keenam adalah kesempatan yang sama untuk semua. Semua mahasiswa sederajat, mereka tidak diperlakukan berbeda berdasarkan kasta, keyakinan, ras, jenis kelamin, agama, dan kecacatan, dll. Alih-alih Pembelajaran Online adalah anugerah bagi pelajar yang cacat dan menghadapi masalah dalam perjalanan dan untuk bagian-bagian dari masyarakat yang tinggal di tempat yang jauh dari perguruan tinggi.

Yang ketujuh adalah memacu diri mahasiswa. Karena perbedaan individu, semua peserta didik tidak dapat menyelesaikan pekerjaan / tugas pada waktu tertentu yang harus mereka hadapi. Pembelajaran online memungkinkan siswa untuk bekerja dan belajar dengan kecepatan mereka sendiri tanpa batasan waktu.

Yang kedelapan adalah

Globalisasi. Teknologi Baru mempersempit hambatan geografis di dunia pendidikan. Dunia telah menjadi tempat sempit dengan peluang untuk mendapatkan informasi tentang negara lain berada dalam akses kita sendiri. Dunia Internet Elektronik menghubungkan orang-orang di seluruh dunia, oleh karena itu, sangat penting untuk bereksperimen dengan pembelajaran elektronik.

Selain keunggulan pembelajaran online terdapat 6 kekurangan pembelajaran online menurut Dhull, I et al (2017), yang pertama adalah komunikasi yang buruk. Dalam pembelajaran online, seseorang tidak memiliki kesempatan untuk melakukan interaksi tatap muka dengan pengajar yang sangat penting untuk menjalin ikatan antara pelajar dan pengajar.

Yang kedua adalah perasaan terisolasi. Pentingnya berinteraksi dengan sesama peserta didik menjadi 
hal penting. Karena kemajuan teknologi di era modern mahasiswa tetap berhubungan dengan teman mereka yang online duduk di tempat yang jauh melalui whatapp, Instagram \& Facebook tapi gagal untuk bertemu dan menyapa seseorang yang duduk di sebelahnya. Kecenderungan ini menyebabkan perasaan terisolasi. Studi menunjukkan bahwa perasaan terisolasi itu sangat besar faktor stres yang mendorong siswa untuk drop out.

Yang ketiga adalah kurangnya motivasi. Pelajar online kurang motivasi saat belajar karena mereka mudah terganggu terhadap hal lain. Bekerja dengan kecepatan mereka sendiri menjadi kerugian bagi mahasiswa yang mengalami kesulitan dengan manajemen waktu dan kecenderungan suka menunda-nunda.

Yang keempat adalah kekurangan dana. Adanya kelemahan teknologi termasuk biaya, perangkat keras masalah, masalah internet, produksi materi kursus dan kekhawatiran tentang ketersediaan dana. Penelitian mengungkapkan bahwa sebagian besar lembaga pendidikan biasanya tidak mengantisipasi biaya konektivitas yang nantinya dapat menyebabkan hambatan untuk online belajar.

Yang kelima adalah kualitas kurang. Pembelajaran Online terkadang berakibat pada kurangnya kualitas dalam proses belajar mengajar.

$$
\text { Yang keenam adalah }
$$

aksesibilitas yang buruk di Daerah Terpencil. Perangkat keras, perangkat lunak dan fasilitas konektivitas adalah prasyarat yang memungkinkan pengajaran dan pembelajaran online. Dengan tidak adanya salah satu dari ini, pembelajaran online tidak dapat mencapai tujuannya. Beberapa orang tidak memiliki akses ke komputer dan koneksi internet, dan beberapa yang memiliki peralatan yang diperlukan merasa tidak dapat menggunakannya.

Kegiatan pembelajaran online pasti menggunakan media yang menjadi wadah pembelajaran online. Media pembelajaran online dapat diartikan sebagai media yang dilengkapi dengan alat control yang dapat dioperasikan oleh pengguna, sehingga pengguna dapat mengendalikan dan mengakses apa yang menjadi kebutuhan pengguna. Adapun contoh pengendaliannya adalah mengunduh materi yang sudah diupload pengajar. Dengan adanya media pembelajaran online, keuntungan yang didapatkan adalah terjadi pembelajaran bersifat mandiri dengan interaksi yang tinggi, sehingga diharapkan bisa meningkatkan pengalaman belajar dengan menggunaan berbagai jenis bahan ajar baik berupa teks, audio, video bahkan animasi dimana setiap bahan ajar digunakan untuk menyampaikan informasi dan berinteraksi.

Pembelajaran online juga bisa disebut sebagai E-learning. E-Learning adalah sebuah sistem pembelajaran jarak jauh melalui pembelajaran elektronik atau yang lebih dikenal dengan istilah E-Learning dengan memanfaatkan internet di dalam bidang pendidikan. Berdasarkan adal katanya, E-Learning terdiri dari $\mathrm{E}$ yang berarti elektronika dan learning yang berarti pembelajaran. Sehingga dapat disimpulkan e-learning adalah sebuah pembelajaran yang menggunakan bantuan perakngkat elektronik. Dan pada pelaksanannnya, E-Learning sendiri bisa menggunakan media seperti audio, video atau perangkat computer dalam penyampaiannya (Tafiardi, dalam Ibrahim, 2014). Elliott Masie, cisco and camellia, dalam Effendy, R (2018) berpendapat bahwa E-learning adalah metode atau sistem pembelajaran yang menggunakan media elektronik baik 
internet, intranet, TV dan sebagainya dalam menyampaikan bahan pembelajarannya. E-learning juga diartikan sebagai proses pembelajaran yang memanfaatkan teknologi informasi komunikasi didalamnya (Martin Jenkins and Janet Hanson, Generic center, dalam Kaurav et al, 2019). Sedangkan di sisi lain, E-learning juga dipahami sebagai proses pengiriman serangkaian solusi yang menggunakan teknologi internet sehingga solusi tersebut bisa meningkatkan pengetahuan dan keterampilan(Rosenberg, dalam Sutopo, 2012) dan E-learning atau internet enable learning adalah sebuah sistem atau metode pengajaran menggunakan teknologi sebagai sarana dalam belajar.

Kepuasan dapat diartikan sebagai perasaan bahagia atau kecewa seseorang yang muncul setelah membandingkan antara hasil yang dicapai dengan harapan yang diinginkan. Jika hasil tidak mencapai harapan maka pelanggan menjadi tidak puas. Sedangkan jika kinerja memenuhi harapan maka pelanggan menjadi puas. Jika hasil melebihi harapan maka pelanggan menjadi amat puas (Kotler, 2012). Pelanggan dalam hal ini adalah mahasiswa. Jadi, kepuasan mahasiswa merupakan fungsi dari persepsi atau kesan atas hasil dan harapan para mahasiswa itu sendiri. Kepuasan juga didefinisikan sebagai suatu sikap yang diputuskan berdasarkan pengalaman yang didapatkan (Lovelock dan Wirtz, 2011). Menurut Tse dan Wilton (1988) dalam Tjiptono (2012) kepuasan pelanggan merupakan respon pelanggan terhadap evaluasi persepsi atas perbedaan antara harapan awal sebelum pembelian (atau standar kinerja lainnya) dan kinerja aktual produk sebagaimana dipersepsikan setelah memakai atau mengkonsumsi produk bersangkutan.

\section{METODE}

Desain penelitian yang digunakan adalah analisis deskriptif. Menurut Linarwati (2016) penelitian deskriptif adalah bentuk penelitian yang bertujuan untuk mendeskripsikan fenomena-fenomena yang ada, baik fenomena alamiah maupun fenomena buatan manusia. Data yang di kumpulkan bersifat deskriptif. Data tersebut tidak bertujuan untuk mencari penjelasan, menguji hipotesis, membuat prediksi, maupun mempelajari implikasi. Populasi dalam penelitian ini adalah semua mahasiswa Universitas Bandar Lampung yang aktif yang mengikuti pembelajaran online sebanyak 5.175 orang mahasiswa. Jumlah sampel penelitian ditetapkan sebanyak 561 orang dengan menggunakan simple random sampling. Data penelitian bersumber dari data primer yang dikumpulkan melalui kuesioner online. Skala penilaian yang digunakan pada kuesioner menggunakan skala likert. Dengan skor terendah 1 sampai dengan skor tertinggi 10. Analisisnya menggunakan metode proporsi (persentase) dan mode (terbanyak menilai berapa).

\section{HASIL DAN PEMBAHASAN}

Penelitian ini menilai kesiapan insfrastruktur jaringan, sistem yang dijalankan, dampak terhadap mahasiswa dan metode yang ditawarkan dalam pembelajaran online. Yang pertama kesiapan infrastruktur jaringan merupakan sejauh mana mahasiswa memiliki fasilitas jaringan untuk bisa mengakses pembelajaran online. Mulai dari alat yang digunakan sampai jaringan internet yang memadai. Karena tidak sedikit mahasiswa yang memilih untuk pulang ke kampung halaman pada saat masa pandemi corona seperti ini, dan belum tentu di daerahnya memiliki sinyal yang baik. Selanjutnya mengenai 
sistem yang dijalankan, pembelajaran online bisa dilakukan dengan berbagai macam pilihan media dan cara. Dalam hal ini, pembelajaran online di UBL menggunakan UBLApps dan ditunjang dengan media pembelajaran lainnya, seperti Zoom untuk pertemuan virtual. Bagaimana pendapat mahasiswa mengenai sistem yang sudah digunakan di UBL. Yaitu pembelajaran online tanpa tatap muka dengan UBLApps dan pembelajaran online dengan tatap muka dengan tambahan aplikasi seperti Zoom dan sebagainya. Pembelajaran online tanpa tatap muka, berarti para dosen hanya mengupload materi dan memberikan tugas di UBLApps. Para mahasiswa tinggal mengakses UBLApps dan kemudian mendownload materi, membaca sendiri dan mengerjakan tugas yang ada. Bahkan untuk UTS dan UAS juga pengerjaannya melalui UBLApps.Sedangkan online dengan tatap muka, adalah bahwa para mahasiswa dan dosen tetap menggunakan UBLApps sesuai dengan fungsinya, namun ditambah dengan adanya pembelajaran dengan video conference menggunakan aplikasi tambahan seperti ZOOM. Dari berbagai pilihan sistem pembelajaran yang ada dan keadaan pandemi yang terjadi, maka perlu diketahui bagaimana dengan minat mahasiswa untuk keberlanjutan studinya.

Walaupun untuk saat ini baik tenaga pengajar atau dosen maupun mahasiswa sudah bisa beradaptasi dengan sistem online yang baru, namun tetap terjadi banyak perbedaan yang dirasakan. Seperti misalnya kontrol kualitas kelas. Adanya kelas pertemuan virtual, dosen tetap bisa menyampaikan materi dan tujuan pembelajaran, namun dosen tidak bisa memonitor sejauh mana mahasiswa memperhatikan dan memahami apa yang telah dijelaskan.
Sehingga penilaian pun menjadi kurang sesuai, karena tidak ada keterkaitan langsung antara dosen dan mahasiswa.

Kemudian adanya sistem pembelajaran baru setelah masa New Normal di UBL. Para mahasiswa dibebaskan untuk memilih antara pembelajaran online, pembelajaran offline atau Flexie learning. Flexie learning yaitu sistem pembelajaran yang dibagi antara offline dan online.

Penelitian ini menggunakan kuesioner dengan skala likert 1-10 dengan pilihan dari sangat tidak sampai dengan sangat iya. 1 sampai dengan 5 berarti responnya negative sedangkan 610 responnya positif. Yang pertama yaitu mengenai kesiapan infrastruktur dan jaringan internet. Kesiapan infrastruktur dan jaringan internet untuk pembelajaran online di kampus Universitas Bandar Lampungsudah sangat memadai, namun bagaimana dengan kesiapan para mahasiswa.

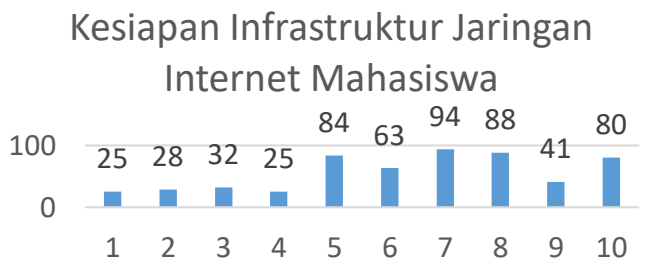

Gambar 1. Kesiapan Infrastruktur jaringan Internet mahasiswa

Ket: 1-10/ Sangat tidak siap sangat siap

Berdasarkan Gambar 1, dapat diketahui bahwa 366 dari 561 mahasiswa merasa sudah memiliki kesiapan infrastruktur jaringan internet. Sedangkan 194 mahasiswa sisanya merasa belum memiliki kesiapan infrastruktur jaringan internet. Berarti 65\% mahasiswa UBL sudah siap melaksanakan program prmbelajaran online dengan infrastruktur jaringan internet yang memadai. 
Kemudian untuk pembelajaran online pada tahun ajaran semester genap 2019/2020 atau awal Tahun 2020 ini, setelah adanya New Normal, terdapat tiga macam model interaksi baik online dengan tatap muka, online tanpa tatap muka dan offline. Kemudian tiga model interaksi tersebut juga dikembangkan lagi sesuai dengan media yang tersedia, seperti Youtube, email, atau video pembelajaran yang diupload di UBLAPPS.

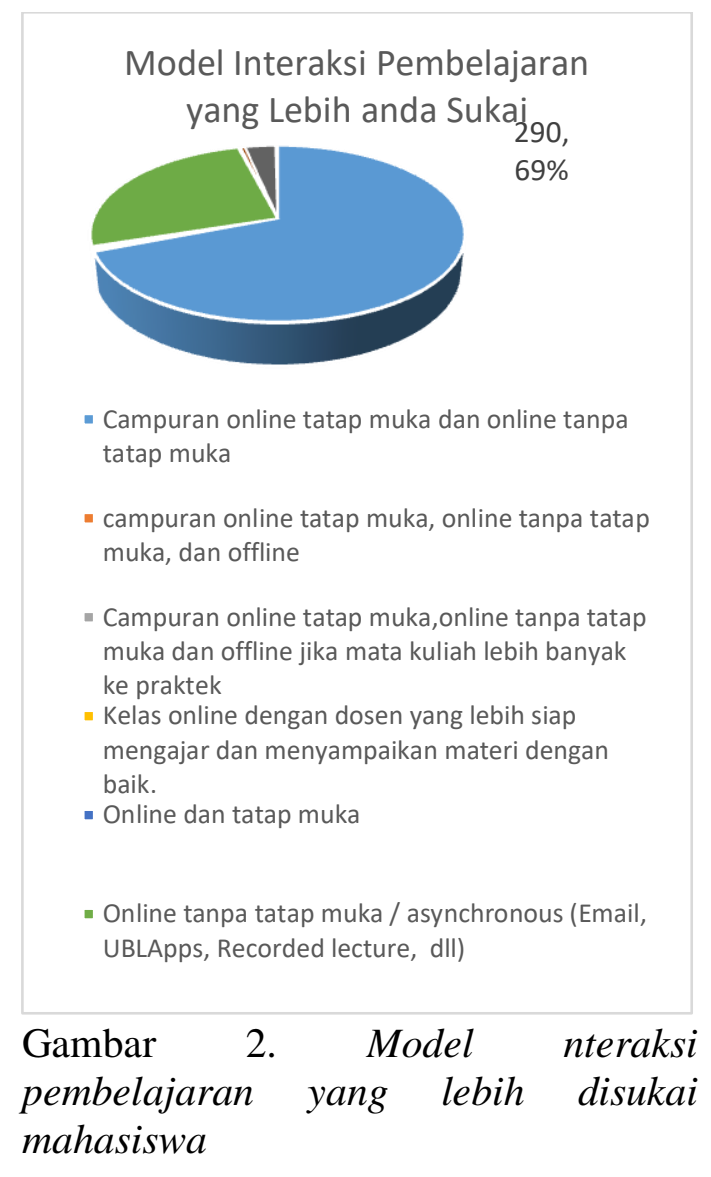

Berdasarkan gambar 2, dapat diketahui bahwa 290 dari 561 mahasiswa memilih model interaksi campuran online tatap muka dan online tanpa tatap muka. Atau 69\% mahasiswa memilih kuliah online dari pada offline dan model interaksi campuran antara tatap muka dan tanpa tatap muka. Dan sisanya baru memilih online tanpa tatap muka, tatapmuka atau offline dan pilihan lainnya. Kemudian bagaimana dengan pemahaman dan kepuasan mahasiswa untuk pembelajaran online baik dengan tatap muka maupun tanpa tatap muka.

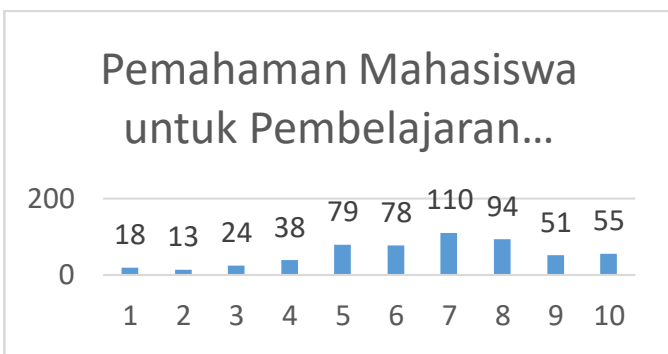

Gambar 3. Pemahaman mahasiswa jika mengikuti pembelajaran online dengan tatap muka

Berdasarkan gambar 3, 388 dari 561 mahasiswa merasa paham dengan metode pembelajaran online dengan tatap muka. Dalam hal ini misalnya pembelajaran online dengan menggunakan aplikasi video conference seperti Zoom. Sisanya 172 orang merasa tidak begitu memahami penjelasan materi dengan menggunakan online tatap muka. Berarti $69 \%$ mahasiswa sudah paham dengan materi pembelajaran online melalui tatap muka.

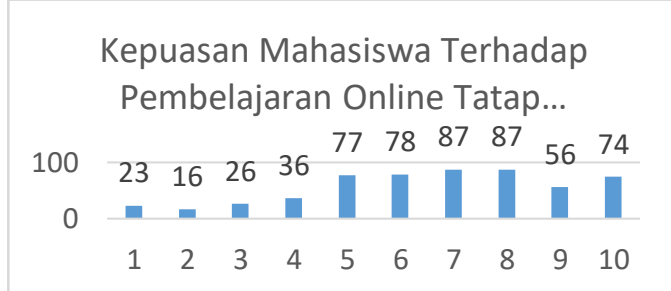

Gambar 4. Kepuasan mahasiswa terhadap pembelajaran online tatap muka

Kemudian berdasarkan kepuasannya, 382 dari 561 mahasiswa sudah merasa puas terhadap pembelajaran online tatap muka yang selama ini mereka ikuti. Sedangkan 182 mahasiswa lainnya merasa belum puas. 
Jadi $68 \%$ mahasiswa sudah merasa puas terhadap pembelajaran online tatap muka. Bagaimana dengan pemahaman dan kepuasan mahasiswa terhadap pembelajaran online atnpa tatap muka. Tanpa tatap muka dalam hal ini berarti, dosen hanya mengupload materi dan memberikan tugas. Kemudian mahasiswa mengakses materi dan mengerjakan tugas secara mandiri.

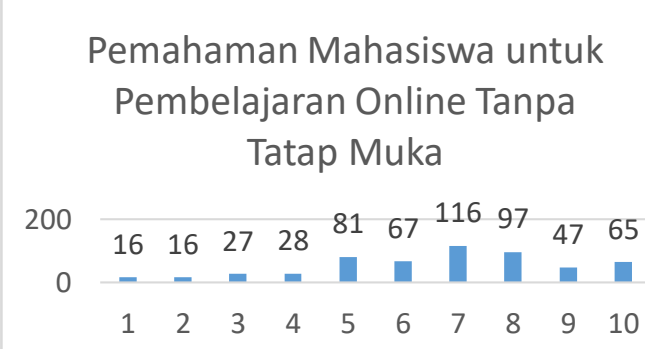

Gambar 5. Pemahaman mahasiswa jika mengikuti pembelajaran online tanpa tatap muka

Berdasarkan gambar 5, dapat dilihat bahwa 392 dari 561 mahasiswa merasa paham dengan metode pembelajaran online tanpa tatap muka. Sisanya 168 orang merasa tidak begitu memahami penjelasan materi dengan menggunakan online tanpa tatap muka. Berarti $69 \%$ mahasiswa sudah paham dengan materi pembelajaran online tanpa melalui tatap muka.

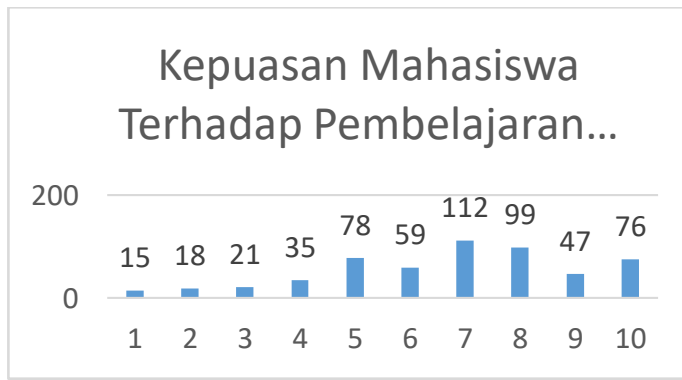

Gambar 6. Kepuasan mahasiswa terhadap pembelajaran online tanpa tatap muka

Berdasarkan tingkat kepuasannya, 393 dari 561 mahasiswa sudah merasa puas terhadap pembelajaran online meskipun tanpa tatap muka dengan dosen. Sedangkan 167 mahasiswa lainnya merasa belum puas. Jadi $70 \%$ mahasiswa sudah merasa puas terhadap pembelajaran online meskipun tatap muka. Selanjutnya secara keseluruhan mahasiswa sudah merasa paham dan puas dengan metode pembelajaran yang dilaksanakan di Universitas Bandar Lampung pada semester genap 2019/2020 atau di awal Tahun 2020 ini. Hal ini terlihat dari 412 dari 561 mahasiswa atau $73 \%$ mahasiswa sudah memahami materi yang diberikan pada pembelajaran online secara keseluruhan.

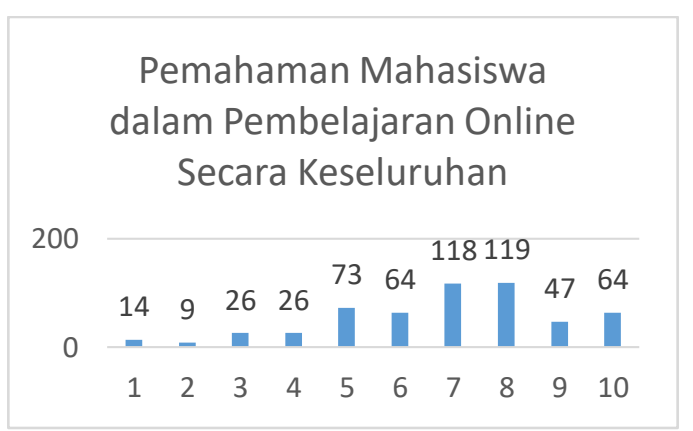

Gambar 7. Pemahaman mahasiswa dalam pembelajaran online secara keseluruhan

Kemudian dari sisi kepuasan, 397 dari 561 mahasiswa atau $70 \%$ mahasiswa merasa puas dengan pembelajaran online yang sudah dilakukan di Universitas Bandar Lampung pada semester genap 2019/2020 ini.

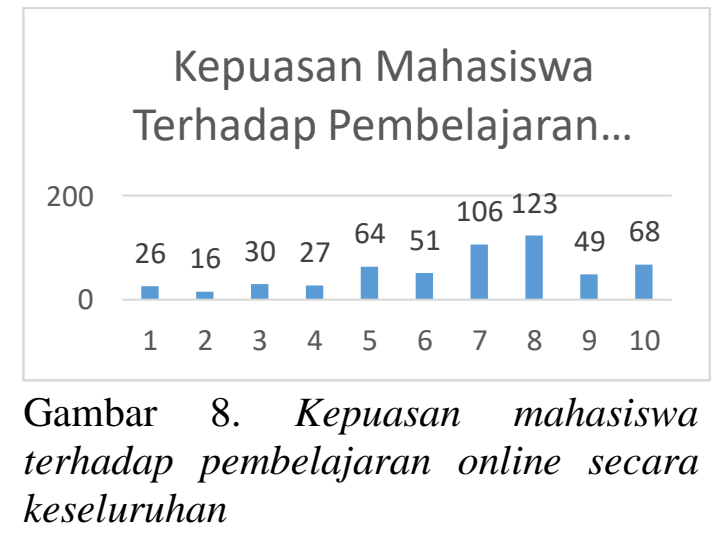


Setelah mengetahui pemahanan dan kepuasan mahasiswa terhadap pembelajaran online yang telah dilakukan di UBL, kemudian bagaimana dengan respon mahasiswa mengenai keberlanjutan studi yang akan mereka ambil, jika perkuliahan tetap dijalankan secara online.

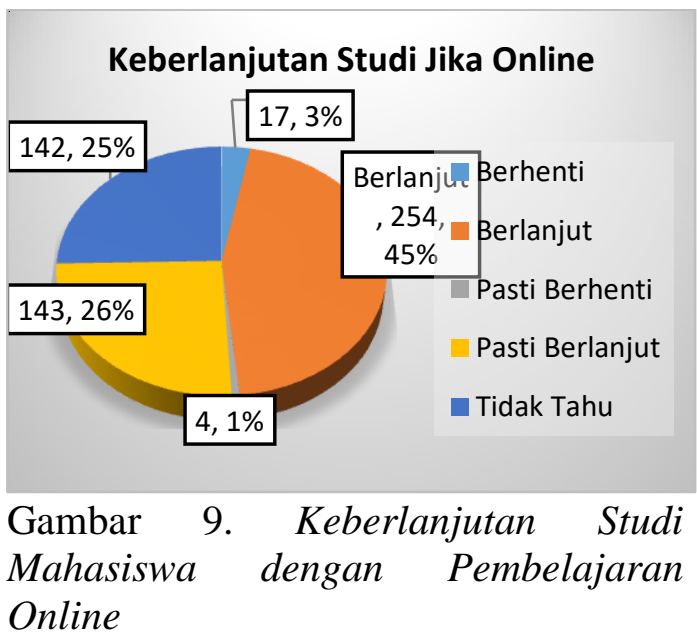

Dari 561 mahasiswa, 4 orang atau $1 \%$ memutuskan untuk pasti berhenti, 17 orang atau 3\% memutuskan untuk berhenti, 142 orang atau $25 \%$ menjawab tidak tahu atau belum tahu ingin berlanjut atau berhenti, 143 orang atau 26\% memutuskan untuk pasti beranjut dan yang terbanyak 254 orang atau $45 \%$ memutuskan untuk melanjutkan kuliah meskipun pembelajaran dilakukan secara online. Berarti jika disimpulkan $71 \%$ mahasiswa memutuskan untuk melanjutkan perkuliahan dnegan pembelajaran online, $25 \%$ mahasiswa masih belum tahu dan sisanya $4 \%$ memutuskan untuk tidak melanjutkan kuliah jika pembelajaran dilakukan secara online. Keputusan ini bisa berdasarkan beberapa faktor seperti ketersediaan jaringan internet, kemampuan menyesuaikan teknologi atau sekedar ketidaksetujuan untuk mengikuti perubahan yang ada.
Setelah mengetahui respon mahasiswa mengenai pembelajaran online yang sudah dijalankan, Universitas Bandar Lampung juga melakukan inovasi tentang metode pembelajaran yang akan dilaksanakan kedepannya. Flexi Learning adalah salah satu metode pembelajaran yang ditawarkan UBL kepada mahasiswa di era new normal. Flexi learning merupakan metode perkuliahan fleksibel dimana mahasiswa akan mendapatkan metode perkuliahan campuran antara online dan offline. Kemudian mahasiswa juga dibebaskan untuk memilih metode perkuliahan antara metode offline, online maupun flexi learning. Seperti yang dijelaskan pada gambar 10, dapat diketahui bahwa 470 dari 561 mahasiswa atau $83 \%$ mahasiswa setuju dengan adanya penerapan flexi learning dan $17 \%$ lainnya kurang setuju.

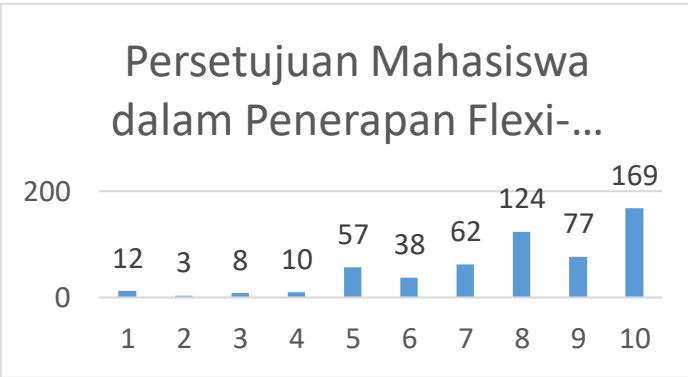

Gambar 10. Persetujuan mahasiswa dalam penerapan flexi learning

Namun jika dilihat pada gambar 11 , ternyata jika diminta untuk memilih antara perkuliahan offline, online maupun flexi learning, $47 \%$ mahasiswa masih memilih untuk kuliah offline, $35 \%$ menginginkan flexi learning dan sisanya $18 \%$ menginginkan kuliah online saja. Berarti masih ada harapan dari mahasiswa agar kondisi kembali normal dan mereka bisa menikmati untuk kuliah secara offline atau campuran antara offline dan online. Hal ini juga dimungkinkan juga karena 
kuliah online membuat para dosen pada akhirnya membuat banyak tugas untuk mengontrol kualitas belajar mahasiswa. Namun hal ini bisa menjadi beban bagi mahasiswa. Menurut Kusnayat et al (2020), terdapat hubungan erat antara sistem perkuliahan online dengan sikap mental mahasiswa. Hal ini terlihat dari $59.5 \%$ mahasiswa yang diteliti merasa bahwa tugas yang diberikan oleh dosen memberatkan sehingga mengakibatkan tingkat stress mahasiswa sebesar $60 \%$. Jika hal ini dibiarkan terjadi secara terus menerus, maka akan berakibat fatal bagi perkembangan psikologis atau kejiwaan mahasiswa. Kemudian terdapat 92\% mahasiswa yang lebih memilih dan lebih senang mengikuti perkuliahan tatap muka di kelas jika dibandingan dengan perkuliahan online.

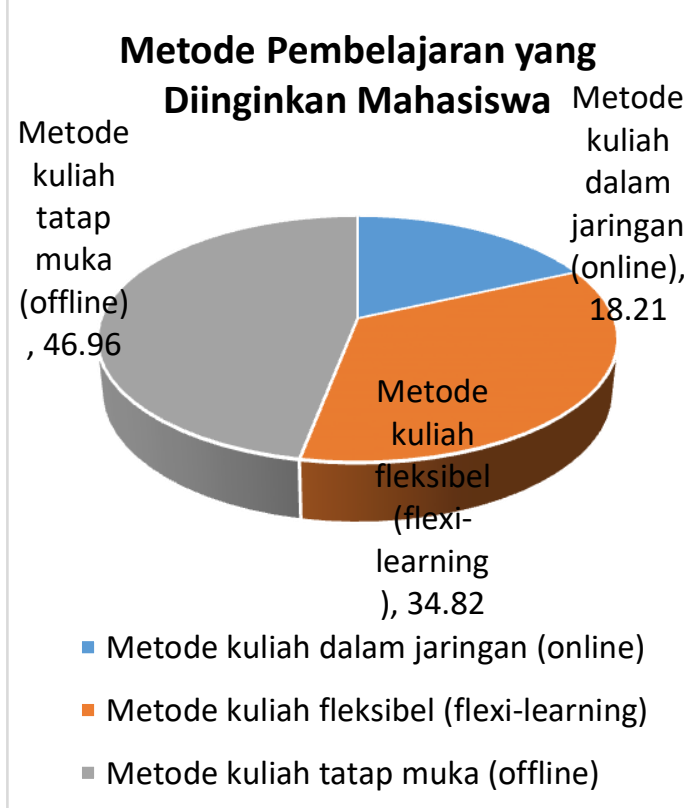

Gambar 11. Metode Pembelajaran yang diinginkan mahasiswa

Selain mengenai metode pembelajaran baik offline, online maupun flexi learning, model pembelajaran berdasarkan waktunya juga menjadi pertimbangan UBL dalam melaksanakan pembelajaran di era new normal saat ini. Waktu pembelajaran yang biasanya dilakukan per semester, UBL mengajukan untuk merubah waktu pembelajaran menjadi sistem periode. Satu semester dibagi menjadi tiga periode. Berarti satu periode adalah 2 bulan. Di dalam sistem periode ini mahasiswa tidak lagi terikat dengan penjadwalan, namuan mahasiswa dipersilahkan untuk menyelesaikan mata kuliah yang diambil pada periode tersebut dan dibebaskan untuk menentukan sendiri kapan harus mengikuti kelas dan mengerjakan tugasnya. Biasanya dalam satu semester terdiri dari maksimal 24 sks atau 8 sampai 12 mata kuliah, dalam satu sistem periode hanya terdiri dari 3 sampai 4 mata kuliah.

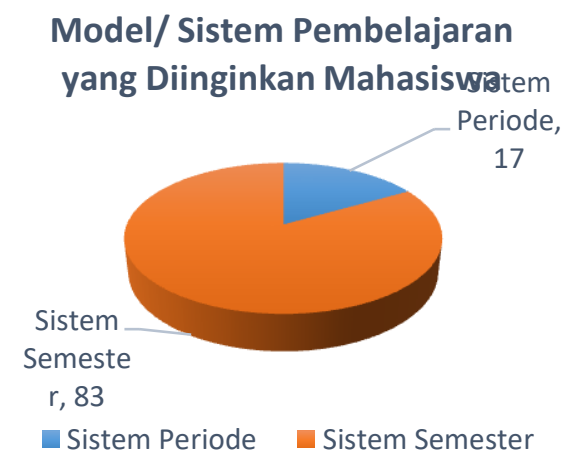

Gambar 12. Model Pembelajaran yang diinginkan mahasiswa

Berdasarkan gambar 12, dapat dilijat bahwa $83 \%$ mahasiswa tetap menginginkan perkuliahan persemester, sedangkan sisanya $17 \%$ setuju untuk mengubah sistem perkuliahan per semester menjadi per periode.

Untuk pembelajaran online di UBL, mahasiswa masih mengharapkan agar kondisi kembali normal dan mereka bisa menikmati kuliah secara offline atau campuran antara offline dan online. Mengenai tugas dalam perkuliahan online, para dosen pada akhirnya membuat banyak tugas untuk mengontrol kualitas belajar mahasiswa. 
Mengenai pembelajaran online di beberapa universitas lainnya, seperti di Universitas Kristen Satya Wacana, pembelajaran online yang dilaksanakan di Universitas Kristen Satya Wacana dinilai berjalan dengan baik. Hal ini terlihat dari meskipun terdapat kendala seperti masalah signal dan kuota mahasiswa, tetapi perkuliahan dapat diselesaikan. Adapun jenis media yang digunakan dalam pembelajaran online adalah menggunakan aplikasi Zoom, Schoology, Edmodo, dan Google Classroom. (Windhiyana et al, 2020)

Selain itu di Universitas Jambi, hasil pembelajaran online yang diketahui adalah mahasiswa sudah mempunyai sarana dan prasarana dasar yang dibutuhkan dalam melakukan pembelajaran online. Adanya fleksibilitas dalam pelaksanaan pembelajaran online berdampak baik pada kemandirian belajar dan motivasi mahasiswa untuk bisa lebih aktif dalam proses pembelajaran. Selain itu pembelajaran online bisa mengurangi keramaian mahasiswa dan mendorong perilaku social distancing sehingga bisa mengurangi potensi penyebaran Covid19 di lingkungan kampus. Sedangkan kendala yang dihadapi adalah masalah infrastruktur jaringan untuk mahasiswa di pelosok, mahalnya biaya kuota dan pengawasan kepada mahasiswa yang lemah. (Sadikin a, et al ).

Kaitannya dengan motivasi belajar mahasiswa, menurut Khairudin et al (2019), kualitas informasi elearning memiliki pengaruh dan hubungan positif terhadap penggunaan e-learning oleh mahasiswa, penggunaan e-laerning memiliki pengaruh dan hubungan positif terhadap motivasi belajar mahasiswa, dan kualitas informasi elearning memiliki pengaruh dan hubungan yang negatif terhadap motivasi belajar mahasiswa.
Memasukkan teknologi dalam
proses pembelajaran belum tentu menjamin siswa menjadi termotivasi. Faktanya, pembelajaran online telah mengakibatkan hubungan mahasiswa dengan dosen menjadi kurang erat atau tidak ada keterikatan. Dosen diwajibkan mengubah ruang kelas menjadi kelas online. Untuk itu perlu diketahui apa sebenarnya yang dibutuhkan seorang dosen atau pengajar untuk memotivasi mahasiswanya dalam pembelajaran online?.

Yang pertama adalah ingat bahwa motivasi harus bersifat alami dalam diri mahasiswa. Kemudian menjelaskan kepada mahasiswanya bagaimana sistem pembelajaran online. Yang ketiga mendorong interaksi dan kolaborasi di antara dosen dan mahasiswa. Selanjutnya membangun kelompok belajar sehingga mahasiswa tidak lagi menjadi mahasiswa belajar dalam isolasi. Yang kelima membantu mahasiswa untuk berteman dengan bertemu dengan sesama mahasiswa di lingkungan online. Yang keenam berinteraksi dengan mahasiswa dengan memantau kehadiran online mereka dan memberi mereka umpan balik yang berkelanjutan. Selanjutnya membangun materi dan lingkungan belajar mereka dengan menargetkan mahasiswa. Kedelapan memfasilitasi interaksi mahasiswa dengan materi online dengan menjelaskan tujuan di balik tugas yang ditentukan. Yang ke Sembilan waspadai ketakutan, kekhawatiran dan kegugupan mahasiswa, karena kecemasan seperti itu mungkin berdampak negative pada aksesibilitas dan motivasi mereka. Semua pendekatan ini bisa menjadi alat penting untuk mengembangkan rencana pengajaran strategis baru yang mungkin membantu dosen untuk mempengaruhi tingkat motivasi pelajar (el-seoud, et al, 2014). 
Sehingga bisa dilihat bahwa ternyata keberhasilan metode elearning di perguruan tinggi hanya dapat diukur menurut keefektifan penyampaiannya. Karena itu dosen di perguruan tinggi atau institusi pendidikan harus menerima, melaksanakan dan mengadopsi kemajuan teknologi yang ditawarkan oleh pembelajaran online. Mulai dari melatih dosen tentang bagaimana menggunakan e-learning untuk meningkatkan pengajaran.

\section{KESIMPULAN}

Pembelajaran online di Universitas Bandar Lampung sudah berjalan sebelum masa pandemi corona dengan menggunakan aplikasi UBLApps. Namun dalam pelaksanaannya, UBLApps hanya digunakan sebagai media mahasiswa mengakses materi dan mengerjakan tugas. Sedangkan pembelajaran online bukan sekedar bisa mengakses materi dan mengerjakan tugas, tetapi harus ada interaksi antara mahasiswa dan dosen. Kesiapan infrastruktur dan jaringan internet untuk pembelajaran online di kampus Universitas Bandar Lampung sudah sangat memadai sedangkan dari sisi mahasiswa, mereka rata-rata sudah siap melaksanakan program pembelajaran online dengan infrastruktur jaringan internet yang memadai. Kemudian dari sisi pembelajaran online, mahasiswa lebih memilih kuliah online dari pada offline dan model interaksi campuran antara tatap muka dan tanpa tatap muka. Selain itu mahasiswa juga sebagian besar sudah merasa paham dengan materi yang diberikan dan puas dengan pembelajaran online yang sudah dijalankan di UBL. Sehingga sebagian besar mahasiswa memutuskan untuk melanjutkan perkuliahan meskipun dengan pembelajaran online. Tidak hanya sekedar pembelajaran online, dalam mengahadapi era new normal, Universitas Bandar Lampung juga menerapkan flexi learning. Sebagian besar mahasiswa setuju dengan adanya penerapan flexi learning. Namun jika diperbolehkan untuk memilih dengan kondisi lingkungan yang normal antara perkuliahan offline, online maupun flexi learning lebih banyak mahasiswa yang menginginkan untuk kuliah secara offline dibandingkan dengan online dan flexi learning. Mengenai waktu pembelajaran yang biasanya dilakukan per semester, UBL mengajukan untuk merubah waktu pembelajaran menjadi sistem periode. Sebagian besar mahasiswa tetap menginginkan perkuliahan persemester dibandingkan per periode. Untuk kedepannya diharapkan UBL bisa menerapkan sistem perkuliahan online yang lebih tertata dengan aplikasi yang lebih memadai. Misalnya dengan sistem yang bisa mengakomodir antara dosen dengan mahasiswa.

\section{DAFTAR PUSTAKA}

BBC. (2020). Pendidikan anak: Hampir 10 juta anak 'berisiko putus sekolah permanen' akibat pandemi Covid19, kata badan amal. BBC News. https://www.bbc.com/indonesia/ma jalah-53385718. 13 Juli 2020.

EFFENDI, R. E., JOYOATMOJO, S. S., \& SULISTYANINGRUM, D. S. (2018). ANALISIS KEBUTUHAN MEDIA ELEARNING BERBASIS SCHOOLOGY DI SMK NEGERI KOTA SURAKARTA. Surya Edunomics, 2(1).

Fandy Tjiptono. (2012). Strategi Pemasaran, ed. 3, Yogyakarta, Andi 
Ibrahim, Doni \& Suardiman, Siti. (2014). PENGARUH PENGGUNAAN E-LEARNING TERHADAP MOTIVASI DAN PRESTASI BELAJAR MATEMATIKA SISWA SD NEGERI TAHUNAN YOGYAKARTA. Jurnal Prima Edukasia. $2 . \quad 66$. 10.21831/jpe.v2i1.2645.

Kaurav, R. P. S., Rajput, S., \& Baber, R. (2019). Factors Affecting the Acceptance of E-learning By Students: A Study of E-learning Programs in Gwalior, India. South Asian Journal of Management, 26(1), 76-95.

Khairudin, K., Rahmi, E., Rahmidani, R., Rusdinal, R., \& Gistituati, N. (2019). ANALISIS KEBIJAKAN PENGGUNAAN E-LEARNING DI UNIVERSITAS NEGERI PADANG. Jurnal Ilmu Sosial dan Humaniora, 8(2), 97-104.

Kusnayat, A., Muiz, MH, Sumarni, N., Mansyur A.S., Zaqiah, QY. (2020). Pengaruh Teknologi Pembelajaran Kuliah Online Di Era Covid-19 dan Dampaknya Terhadap Mental Mahasiswa. Jurnal Edukasi dan Teknologi Pembelajaran. EduTeach. Vol 1, No 2.

Kotler, Philip. 2012 Manajemen Pemasaran, Edisi Pertama. Indonesia: PT. Indeks Kelompok Gramedia.

Linarwati, M., Fathoni, A., \& Minarsih, M. M. (2016). Studi deskriptif pelatihan dan pengembangan sumberdaya manusia serta penggunaan metode behavioral event interview dalam merekrut karyawan baru di bank mega cabang kudus. Journal of Management, 2(2).

Lovelock, C, dan John Wirtz, (2011). "Pemasaran Jasa Perspektif edisi 7". Jakarta : Erlangga.

Moore, J. L., Dickson-Deane, C., \& Galyen, K. (2011). e-Learning, online learning, and distance learning environments: Are they the same?. The Internet and Higher Education, 14(2), 129-135.

Sadikin, A., \& Hamidah, A. (2020). Pembelajaran Daring di Tengah Wabah Covid-19:(Online Learning in the Middle of the Covid-19 Pandemic). Biodik, 6(2), 214-224.

Samir, M., Abou, E. S., Taj-Eddin, A. I., \& Mahmoud, M. (2014). E-Learning and Students' Motivation: A Research Study on the Effect of ELearning on Higher Education. International Journal of Emerging Technologies in Learning, 9(4), 20-26.

Sutopo, Ariesto Hadi. (2012). Teknologi Informasi dan Komunikasi dalam Pendidikan. Yogyakarta: Graha Ilmu.

Windhiyana, E. (2020). Dampak Covid19 terhadap kegiatan pembelajaran online di sebuah perguruan tinggi kristen di Indonesia. Perspektif Ilmu Pendidikan, 34(1), 1-8. 